\title{
«МАЙСТЕР КОРАБЛЯ» ЮРІЯ ЯНОВСЬКОГО: ОБРАЗ ОПОВІДАЧА ЧЕРЕЗ ТЕКСТ І КОНТЕКСТ
}

У статті йдеться про роль постаті оповідача в оприявленні ключової філософської ідеї «Майстра корабля» Юрія Яновського - утвердження необхідності плекання пізнаних в юнацтві людських «порухів». Охарактеризовано специфіку сучасної дослідницької рецепції романної спадщчини мития.

Обтрунтовано філологічну проблему автора як актуальну в процесі дослідження змістової та поетикальної сфер твору. Увиразнено специффіку художнього світу як такого, щзо містить авторське бачення, осмислення, оиінку довколишнього та власного «я» в ньому. Пояснено, як інтерпретація зовнішнього і внутрішнього світів тексту формує естетичне уявлення про авторську індивідуальну картину світу (iї зміст, час і простір), а відтак і про самого художньо вираженого автора (набутий і очікуваний внутрішній досвід, інтереси, уподобання, иінності, якості).

Акцентовано на меті дослідити найбільи репрезентативні щуодо внутрішнього та зовнішнього світів оповідача текстуальні та контекстуальні аспекти роману «Майстер корабля» Юрія Яновського.

Охарактеризовано такі аспекти художньо вираженого досвіду оповідача: екзистениійна закономірність енергопрочесів Всесвіту, сакральність світу кіномистецтва та сфери духовного загалом, унікальність творчої діяльності та творчої особистості, закономірності людської природи тощзо.

Окреслено художньо вираженого автора як харизматичну особистість, щуо володіє проникливою спостережливістю, критичністю мислення, дієвою життєвою мудрістю, фаховою компетентністю, стойцизмом $i$ безкомпромісністю в досягненні необхідного, романтичністю світосприймання, вразливістю натури тощяо.

Зроблено акиенти щзодо якості літературознавчого опанування тексту «Майстер корабля» з позиції художньо вираженого автора. Наголошено на необхідності доповнення отриманих результатів іншими методиками або кониепиіями дослідження біографічної постаті та творчої спадщчини Юрія Яновського.

Ключові слова: проблема автора, образ оповідача, зовнішній світ, внутрішній світ, текст, контекст.

Oleksandra TSEPA, orcid.org/0000-0001-9282-4215

Candidate of Philological Sciences, Associate Professor, Associate Professor at the Department of Ukrainian and Foreign Literature Volodymyr Vynnychenko Central Ukrainian State Pedagogical University (Kropyvnytskyi,Ukraine) tsepaov@gmail.com

\section{THE “MASTER OF THE SHIP” WRITTEN BY YURI YANOVSKY: THE IMAGE OF THE NARRATOR THROUGH THE TEXT AND CONTEXT}

The article tells about the role of the narrator's figure in the manifestation of the key philosophical idea of the "Master of the ship" written by Yuri Yanovsky - this is the affirmation of the need to cherish the human "movements" known from youth. The specifics of the modern research reception of the artist's novel heritage are characterized in the article.

The author's philological problem is substantiated as relevant in the process of studying the content and poetic spheres of the work. The article highlights the specifics of the artistic world as such, which contains the author's vision, understanding, assessment of others and their own "I" in it. It explains how the interpretation of the external and internal worlds of the text forms an aesthetic idea of the author's individual picture of the world (its content, time and space), and therefore of the artistically expressed author himself (acquired and expected internal experience, interests, preferences, values, qualities).

The article focuses on the purpose of exploring the textual and contextual aspects of the novel "Master of the ship" written by Yuri Yanovsky, which are most representative of the inner and outer worlds of the narrator.

The article characterizes the following aspects of the narrator's artistically expressed experience: the existential regularity of the energy processes of the universe, the sacredness of the world of cinema and the spiritual sphere as a whole, the uniqueness of creative activity and creative personality, the laws of human nature, and so on. 
The author, who is artistically expressed, is defined as a charismatic person who has insightful observation, critical thinking, effective life wisdom, professional competence, stoicism and uncompromising in achieving the necessary, romantic perception of the world, impressionability of nature, and so on.

Emphasis are placed on the quality of literary development of the text "Master of the ship" from the point of view of an artistically expressed author. The article notes the need to supplement the results obtained with other methods or concepts for studying the biographical figure and creative heritage of Yuri Yanovsky.

Key words: author's problem, narrator's image, external world, internal world, text, context.

Постановка проблеми. Епіграф твору - слова М. Гоголя про життєво необхідне для дорослого стоїцизму плекання пізнаних в юнацтві людських «порухів» - увиразнює відповідну філософську ідею, оригінально осмислену автором у художньому світі роману загалом і через постать оповідача зокрема. У цьому контексті рядки Гете, Дібдіна, Горація неоромантичними мотивами мандрівки, свободи, кохання додають необхідної експресивної тональності.

Аналіз досліджень. Останніми роками романи Юрія Яновського, зокрема й «Майстер корабля», розглядалися в аспектах: «новаторського характеру» (Бернадська, 2003), «літературної містифікації» (Панченко, 2002), кінематографічної специфіки (Пуніна, 2010), «речовості» та «субстанційності алхімічної символіки» (Городнюк, 2017), так званої одеської теми (Саєнко, 2014), «мотиву повернення на Батьківщину» (Заверталюк, 2012), «естетики і естетизму» (Голобородько, 2007), «онімного простору» (Шотова-Ніколенко, 2007), «функції екфразису» (Бестюк, 2013) тощо.

Мета статті. У сучасній літературно-критичній думці фахівці все частіше враховують авторську позицію в процесі пізнання як змістової, так і поетикальної сфер тексту. Нині немає сумнівів у тому, що автор як організатор художнього світу має бути епіцентром і різного роду часткових інтерпретацій твору, і його цілісного осягнення. Зрештою такий дослідницький підхід має здатність максимально унеможливлювати різного роду перекручення й фальсифікації під час трактування світоглядної та творчої специфіки митця. Дослідження роману Ю. Яновського в ракурсі проблеми автора, на нашу думку, найефективніше сприятиме увиразненню його ключових текстуальних нюансів та контекстуальних аспектів.

Художній світ будь-якого твору містить авторське бачення, осмислення, оцінку довколишнього (явища, події, люди тощо подані крізь призму інтелекту, світовідчуття, цінностей творчої особистості) та власного «я» в ньому. Реципієнт/дослідник, осягнувши ці взаємозумовлені образи - зовнішнього і внутрішнього світів сформує естетичне уявлення про авторську індивідуальну картину світу, а відтак і про самого художньо вираженого автора (Цепа, 2014: 8-78).
У прозовому творі автора, за Б. Корманом, презентують «суб' єктні» форми («оповідач» і «розповідач») разом із «позасуб'єктною організацією» (певним відбором явищ навколишньої дійсності, через композицію, сюжет, зображально-виражальні засоби і т. д.) (Корман, 1971: 205).

Найефективніше в романі Яновського досліджувати специфіку образу зовнішнього світу, звертаючи увагу на те, «кого» та «що» бачить оповідач, як та наскільки глибоко осмислює цих «когось» i «щось», яким є його ставлення до зображеного. Дослідження специфіки бачення оповідача, тобто пошук і систематизація в тексті компонентів довколишнього, увиразнить змістову, часово-просторову характеристику образу зовнішнього світу. 3'ясування особливостей презентованого експліцитним та імпліцитним змістом тексту осмислення і ставлення оповідача до виокремлених складників дасть змогу окреслити інтереси, уподобання, цінності, якості художньо презентованої особистості оповідача, обгрунтувати їхню функціональну роль та ідейне навантаження, простежити еволюційні зміни.

Під час дослідження в романі «Майстер корабля» образу внутрішнього світу необхідно зосередитися на аналізі/інтерпретації системи самопрезентувань оповідача: самозображень, самооцінок, самоочікувань. Осмислення згаданих аспектів художнього «я» дасть змогу отримати інформацію про набутий і очікуваний внутрішній досвід автора.

Зауважимо, що в межах статті зосередимося тільки на тих текстуальних і контекстуальних аспектах роману «Майстер корабля» Юрія Яновського, які, на нашу думку, є найбільш репрезентативні щодо внутрішнього та зовнішнього світів оповідача - однією з так званих суб'єктних форм вираження художнього автора.

Виклад основного матеріалу. У межах нашого предмета дослідження вагомим $є$ початок роману. Максимально сконденсовані в одному абзаці ключові аспекти самозображення, самооцінки й самоочікування То-Ма-Кі відіграють роль своєрідної «прологової настроєвості» на постать художнього автора, який має три «козирі» в утриманні уваги читача: поважний вік, багатий досвід, настирливе відчуття 
обов'язку. Останнє, увиразнене оповідачем двічі («сиве волосся до чогось зобов'язує»; «старість до чогось зобов'язує») (Яновський, 2020: 5), не тільки переконує у важливості озвученого прагнення, але й, поки що неконкретизоване, привносить в оповідь дієву інтригувальну тональність.

Образ «прекрасного вогника, символу вічного переходу енергії й розкладу матерії» (Яновський, 2020: 5) передає усвідомлення оповідачем неминучості власної тілесної тлінності та закономірності залучення його в безперервний енергообмін - віддачу енергоресурсів, здобутих окремим життям, у конкретному матеріальному вимірі. Дієву мудрість оповідача, повагу до його особистості та авторитетність слова підсилено образним твердженням про вогник, який «грiє... долоні» (Яновський, 2020: 5) (читай: ще підживлює мене; уже готується забрати у вічність надбане мною i т. п.). Надалі оповідач, оцінюючи свої («не висли безсило від розпачу та невдачі, ... завжди чесно служили мені») (Яновський, 2020: 43) та висловлюючи своєрідну оду людським рукам загалом, не тільки увиразнить різноаспектні нюанси символічної природи відповідного художнього образу («...жорстокі ци хижащькі, руки праизовиті й ледарські, руки мужчини й жінки!»; «здаються живими додатками до людського розуму»; «творчі пальиі - тремтячі й нервові»), але й доповнить ще на початку твору заявлені відповідні медитативні акценти, міркуючи про особливості творчої енергії («Перо $i$ пензель, ніж і сокира, талановитий молоток! Чи знаєте ви, щзо рука, яка вас тримає, передає через вас вогонь життя? Вона вмре, ия невгамовна рука, а витвори ї̈ житимуть»), енергосистему окремої людини («коли друг дає руку другові: ичим він передає самого себе, своє серие й розум, дихання дітей»), спільне енергетичне поле («дві людських руки вкупі-ие кільце, за яке, ухопившися, можна зрушити землю») (Яновський, 2020: 42).

Приязне налаштування та довіра реципієнта суттєво підсилені авторським одкровенням про намір віддати «на суд» власні «юнащькі помилки ŭ перемоги», щоб у «молодих, сміливих і чуйних» не тільки «збудити... думки», але й спонукати їх «на шуккання яскравіших просторів і горизонтів» (Яновський, 2020: 19). Авторитетності слова, як і харизматичності самому образу оповідача, переконливо сприяє зізнання То-Ма-Кі у власному «бунті» проти звичної усталеності, передбачливої протореності («Я ніколи не любив ходити по дорогах. Томуя йлюблюморе, що на ньому кожна дорога нова і кожне місие - дорога»), як і твердження про чітку життєву настроєвість, безкомпромісність і стоїцизм у досягненні необхідного («Треба не губити напрямку, бачити попереду верхів'я гори й іти крізь хащіџ)) (Яновський, 2020: 27).

Резюмуючи власні спостереження над специфікою кіноконструкції в романі «Майстер корабля», дослідниця О. Пуніна переконує, що «роман із кінематографічною основою виростає на органічному синтезі художньо-літературних поглядів письменника із природно-кінематографічним баченням та суто технічними настановами автора в кіногалузі» (Пуніна, 2010: 48). У межах нашого предмета дослідження додамо, що відчуття та роздуми оповідача стосовно специфіки кіномистецтва віддзеркалюють суттєві аспекти його життєсвіту. Скажімо, пригадуючи приїзд до кінофабрики, То-Ма-Кі акцентує на своєму романтичному світосприйманні («Я, підскакуючи, ходив до міста, дивувався на море й забивав голову різною романтикою») (Яновський, 2020: 11). Розповідь про перші «кроки в кіно» (Яновський, 2020: 6) оприявлює чутливу душевну організацію художнього редактора. Самотність, до речі, підживлюватиме вразливість натури і в поважному віці («Гей, однолітки, чи й вам так болить часом серие? Та де! - Тих узяла могила, а решта замкнулася в баштах поважної старості» (Яновський, 2020: 6), «Родини я не маю. Розлетілися всі по світі, розійшлися» (Яновський, 2020: 7).

Перегляд окремих кадрів стрічки «Біла Пустеля» увиразнює відчуття сакральності у ставленні до жінки-матері, продукує життєствердні акорди: «О найсвященніша радосте народження дитини! О глибока поваго до мук матері! О радість життя!» (Яновський, 2020: 9).

Реакція оповідача на музикантів та акторів під час театральної вистави про Йосифа Прекрасного, проданого братами в рабство єгиптянам, засвідчує компетентну й надзвичайно чутливу до мистецтва людину. Органічними в цьому контексті $€$ також образні рефлексії-міркування сімдесятилітнього То-Ма-Кі про «наречену, щчо для неї... жив иіле життя, їй присвятив сталеву шпагу й за неї підставляв під мечі важкий щит» - «культуру нації» (Яновський, 2020: 30). Таке саможертовна настроєвість до сфери духовного закономірно активувала відповідні лідерські риси оповідача: гордість, сміливість і впертість.

Проникливу спостережливість, критичність мислення оповідача спостерігаємо в розлогих описах нюансів професійної співпраці режисера і сценариста, чіткому усвідомленні запоруки кінематографічного успіху: «Коли режисер ставить сиенарій, <..> він мусить твердо засвоїти основну авторську думку, тему, проблему» (Янов- 
ський, 2020: 21). Для філологічної проблеми автора цінними $є$ роздуми оповідача про суть творчості в аспекті егоїзму та егоцентризму, про постать романіста та нюанси його творчої лабораторії («автор ховається за лаштунками, а його герої ходять по сиені, коли він шарпає за шпагатинку») (Яновський, 2020: 28), специфіку мемуарної літератури та унікальну «свободу» автора спогадів («Згадую певний шиаток життя, щчо мені він дорогий, і пишу про нього. Я не боюсь, що мій читач почне нудьгувати або йому не сподобається усмішка героїні. Коли б я писав романа, я за иим стежсив би і мені не тяжко було б смикати героїв за ниточки, сидячи за сиеною. Однаково - героїв видумано, герої безсловесні для їхнього автора, і він може ними керувати. Інша справа тепер. Я пишу насамперед для себе, і мені все иікаве. Я, може, не хочу показувати красивої, витонченої будівлі, а хочу так дати матеріал, щьоб у кожного читача виріс в уяві свій окремий будинок художнього впливу. Той, кому тяжко буде прочитати до кіния, може відкласти книжку. Я не ображусь так, як образився б романіст. Значить, іше не час йому читати мої мемуари. Я, лежачи в могилі, можу почекати ще сотнюдругу років») (Яновський, 2020: 28-29).

У контексті психології творчої особистості привертають увагу акценти То-Ма-Кі про унікальність «радісної прачіi» (Яновський, 2020: 145) та «творчої роботи» (Яновський, 2020: 121): перша - «ознака творчості» (Яновський, 2020: 145), друга - джерело неймовірної витривалості, життєвої енергії, вітаїзму (людина забуває «за втому $i$ за їжу, $i$ десь з'являються подвійні сили, почетверена енергія і повосьмерена жвавість і веселість») (Яновський, 2020: 121). У такому контексті суттєво увиразнюється символічність фінальних мемуарних зізнань сімдесятилітнього оповідача: «Але й нині я гостро відчуваю запах саду, що я посадив» (Яновський, 2020: 121).

Розвинена змолоду звичка придивлятися й оцінювати людей знаходить своє неодноразове підтвердження в проникливих описах-міркуваннях оповідача про Директора кінофабрики; Професора; художника Сева; Тайах; матроса Богдана; представників знімальної групи, акторів оперного театру, комісара закордонних справ; турецького міністра, рибалок та ін. Представлена галерея постатей переконливо ілюструє людинознавчі знання і вміння оповідача: «відрізняти людей від тих речей, серед яких вони живуть», «вийняти людину з декораиії, яку вона собі сама або інші ій збудували, і порозмовляти з такою людиною, позбавленою оточення» (Яновський, 2020: 25).
Відповідний досвід рафінує смаки оповідача: «Я взагалі люблю людей, з якими можна розмовляти, не кажучи всіх слів» (Яновський, 2020: 40).

Не раз акцентоване вікове самозображення (цікавими у функціональному аспекті $\epsilon$ різнозаряджені акценти і про «останні роки, як краплі старого незабутнього вина», що він їх п'є, «не знаючи, коли йому вийде край» (Яновський, 2020: 10), і про відчуття здатності «жити іще пів сотні років» (Яновський, 2020: 36) разом із епатажною морально-етичною самооцінкою ( $Я$ жорстокий» (Яновський, 2020: 9), «Мені ... - однаково, щуо про мене скажуть. ... Я не можу гніватись, бо немає людини, яка могла б заподіяти щось достойне мого гніву» (Яновський, 2020: 10), неординарним самоусвідомленням («Мойх років людина живе мозком»; «Я тепер усвідомив своє місие серед мільярдів літ людства, серед астрономічної кількості людських створінь і на мікроскопічній планеті» (Яновський, 2020: 9); «Я стою на високому щаблі, $і$ мої роки дають мені можсливість із неприступної гори оглядати місиевість. Без захоплення дрібнииями. Без гніву. Без жалощів. Без страху. Без особливих переживань і ненависті. В холодній старечій любові до найпрекрасного (о, повірте мені), що я знав у світі, - до Життя» (Яновський, 2020: 10) - стають запорукою довіри до філософських узагальнень оповідача про аксіологічні аспекти людської природи: дочасність $\boldsymbol{i}$ тлінність людського буття («...помилку робить той, хто поспішає... I здаватиметься, і летітиме він, не знаючи, що все на світі є перебіжне й немає ніде чудес і тайн» (Яновський, 2020: 10); закономірну невідворотність $\boldsymbol{i}$ невблаганність часових змін («Юнак хоче бути досвідченим і старішим, а прийшовщи до цьвого всього, жагуче бажає повернути наївні, нерозумні дні» (Яновський, 2020: 18); конфлікт поколінь як природний етап закону існування («Зрозумійте психологію старості, юначе. Народивши вашого батька, ми все життя вважали себе старшим $i$ розумнішим за нього. Вас ми констатували, як периу пересторогу й нагадування про Потойбічне. Звичайно, ми з вами серйозно рахуватися не могли. Ми навіть вороже дивимось на вас, бо ви женете нас до могили. Ви випиваєте наше погасання, красуєтесь і ростете. В иььму - закон існування. Пам'ятайте тільки, щуо ви теж будете такими, як ми, - стережіться вимовити поквапне слово» (Яновський, 2020: 19); епатажність, руйнування стереотипності відчуттів, думок $і$ поведінки («Людина без ідеалів, бо не знає авторитетів, без ворогів, бо вважає, щчо друг $і$ ворог - два обличчя одного тіла, егоїст, бо не знає нікого не егоїста, ичнік, бо так називають людей з їхніми думками, 
працівник і ледар в один час, бо думає, щзо людина працює для ліні ци лінується для того, щзоб працүювати» (Яновський, 2020: 30); відууття жсалю («Бо жаль - недостойне почуття, воно зневажає того, кого ми жаліємо. Воно привчає декого, щуоб їх так зневажали» (Яновський, 2020: 9-10) тощо.

Зауважимо, що вищевказані аспекти самозображення / самооцінки / самоусвідомлення разом iз двічі повтореною Професором риторично зарядженою характеристикою особистісних якостей То-Ма-Кі - «Чи маєте ви самі всю ту енергію й завзяття, упертість і хоробрість, щуо ви їх збуджуєте в інших?»; «чи маєте ви самі ту енергію й завзяття, котрі видобуваєте ви з людей, ніби торкнувши їх біблейським посохом Мойсея?» (Яновський, 2020: 127) - дають вагомі підстави говорити про унікальність власного внутрішнього досвіду оповідача та неординарність сприймання його довколишніми.

Висновки. Отже, зосередження на ключових аспектах тексту i контексту роману «Майстер корабля» Юрія Яновського (екзистенційна закономірність енергопроцесів Всесвіту, сакральність світу кіномистецтва та сфери духовного загалом, унікальність творчої діяльності та творчої особистості, закономірності людської природи тощо) дало змогу розкодувати суттєве в зовнішньому та внутрішньому світах оповідача, а відтак окреслити художньо вираженого автора як харизматичну особистість, осердям магнетичної привабливості якої є: прониклива спостережливість, критичність мислення, дієва життєва мудрість, фахова компетентність, стоїцизм і безкомпромісність у досягненні необхідного, романтичність світосприймання, вразливість натури тощо.

Дослідження з позиції проблеми автора роману «Майстер корабля» $є$, на нашу думку, черговою спробою не тільки урізноманітнення літературознавчої рецепції тексту Юрія Яновського, але й наближення до «таїни» його біографічної та творчої постаті. Наші результати аналізу/інтерпретації художньо вираженої авторської особистості можуть бути доповненням чи підгрунтям для низки інших методик або концепцій дослідження як цього тексту, так і загалом творчої спадщини Юрія Яновського.

\section{СПИСОК ВИКОРИСТАНИХ ДЖЕРЕЛ}

1. Бернадська Н. Новаторський характер роману Ю. Яновського «Майстер корабля». Літературознавчі студіï. Київ : ВПЦ «Київський університет», 2003. Вип. 4. С.14-19.

2. Бестюк I. «Кущ» Вінсента ван Гога: функції екфразису в романі «Майстер корабля» Юрія Яновського. Мандрівец̧ь. 2013. № 6. C. 46-51. URL: http://nbuv.gov.ua/UJRN/Mandriv_2013_6_13 (дата звернення: 16.08.2020).

3. Голобородько Я. Естетика і естетизм Юрія Яновського (романи «Майстер корабля», «Чотири шаблі», «Вершники»). Украӥнська мова і література в школі. 2007. № 5. С. 50-60.

4. Городнюк Н. Речовість та субстанційність алхімічної символіки у романі Ю. Яновського «Майстер корабля». Проблеми сучасного літературознавства. 2017. Вип. 24. С. 141-146.

5. Заверталюк Н. Мотив повернення на Батьківщину в романі «Майстер корабля» Ю. Яновського. Тайни художнього тексту (до проблеми поетики тексту). 2012. Вип. 14. С. 30-40. URL: http://nbuv.gov.ua/UJRN/Tkht_2012_14_6 (дата звернення: 19.08.2020).

6. Корман Б. Итоги и перспективы изучения проблемы автора. Странищы русской литературы / отв. ред. Д. Марков. Москва : Наука, 1971. С. 199-207.

7. Патетичний фрегат : Роман Юрія Яновського «Майстер корабля» як літературна містифікація / упоряд. В. Панченко. Київ : Факт, 2002. 344 с.

8. Пуніна О. Кіноконструкція в романі Юрія Яновського «Майстер корабля». Слово $і$ час. 2010. № 11. С. 41-50.

9. Саєнко В. «Голлівуд на березі Чорного моря» в інтерпретації митців доби Розстріляного Відродження: літературознавство і компаративістика. Дивослово. 2014. № 7-8. С. 58-63.

10. Цепа О. Образ автора в поезіях Тараса Шевченка до заслання. Кіровоград : ПП «Центр оперативної поліграфії «Авангард», 2014. 260 с.

11. Шотова-Ніколенко Г. Онімний простір романів Юрія Яновського. Одеса : Астропринт, 2007. 168 с.

12. Яновський Ю. Майстер корабля. Київ : Знання, 2020. 175 с.

\section{REFERENCES}

1. Bernadska N. Novatorskyi kharakter romanu Yu. Ianovskoho "Maister korabli” [Innovative character of Yu. Yanovsky's novel "Master of the ship"]. Literaturoznavchi studii. K. : VPTs "Kyivskyi universytet", 2003. Vyp. 4. P. 14-19 [in Ukranian].

2. Bestiuk I. "Kushch" Vinsenta van Goga: funktsii ekfrazysu v romani "Maister korablia" Yuriia Yanovskoho [Vincent van Gogh's "Bush”: the functions of ekphrasis in Yuri Yanovsky’s novel The Ship Master]. Mandrivets. 2013. № 6. P. 46-51. URL: http://nbuv.gov.ua/UJRN/Mandriv_2013_6_13 (data zvernennia: 16.08.2020) [in Ukranian].

3. Holoborodko Ia. Estetyka i estetyzm Yuriia Yanovskoho : (romany "Maister korablia", "Chotyry shabli", "Vershnyky") [Aesthetics and aestheticism of Yuri Yanovsky: (novels "Master of the Ship", "Four Swords", "Horsemen")]. Ukrainska mova i literatura v shkoli. 2007. № 5. P. 50-60 [in Ukranian].

4. Horodniuk N. Rechovist ta substantsiinist alkhimichnoi symvoliky u romani Yu. Ianovskoho "Maister korablia" [Substance and substantiality of alchemical symbolism in Yu. Yanovsky's novel The Master of the Ship]. Problemy suchasnoho literaturoznavstva. 2017. Vyp. 24. P. 141-146. [in Ukranian]. 
5. Zavertaliuk N. Motyv povernennia na Batkivshchynu v romani "Maister korablia" Yu. Ianovskoho [The motive for returning home in the novel "Ship of master" by Yu. Yanovsky]. Tainy khudozhnoho tekstu (do problemy poetyky tekstu). 2012. Vyp. 14. P. 30-40. URL: http://nbuv.gov.ua/UJRN/Tkht_2012_14_6 (data zvernennia: 19.08.2020) [in Ukranian].

6. Korman B. Itogi i perspektivy' izucheniya problemy' avtora [Results and prospects of studying the author's problem]. Straniczy’ russkoj literatury'/ otv. red. D. Markov. M. : Nauka, 1971. P. 199-207 [in Russian].

7. Patetychnyi fregat : Roman Yuriia Yanovskoho "Maister korablia" yak literaturna mistyfikatsiia / uporiad. V. Panchenko [Pathetic Frigate: Yuri Yanovsky's The Master of the Ship as a Literary Mystification]. K. : Fakt, 2002. 344 p. [in Ukranian].

8. Punina O. Kinokonstruktsiia v romani Yuriia Yanovskoho "Maister korablia" [Film construction in Yuri Yanovsky's novel "Master of the Ship"]. Slovo i chas. 2010. № 11. P. 41-50. [in Ukranian].

9. Saienko V. "Hollivud na berezi Chornoho moria" v interpretatsii myttsiv doby Rozstrilianoho Vidrodzhennia: literaturoznavstvo i komparatyvistyka ["Hollywood on the Black Sea" in the Interpretation of Artists of the Shoot Renaissance: Literary Studies and Comparative Studies]. Dyvoslovo. 2014. № 7-8. P. 58-63 [in Ukranian].

10. Tsepa O. Obraz avtora v poeziiakh Tarasa Shevchenka do zaslannia [The image of the author in the poems of Taras Shevchenko to exile]. Kirovohrad : PP "Tsentr operatyvnoi polihrafii "Avanhard”, 2014. 260 p. [in Ukranian].

11. Shotova-Nikolenko H. Onimnyi prostir romaniv Yuriia Yanovskoho [The onymic space of Yuri Yanovsky's novels]. Odesa : Astroprynt, 2007. 168 p. [in Ukranian].

12. Yanovskyi Iu. Maister korablia [Ship master]. K. : Znannia, 2020. 175 p. [in Ukranian]. 